\title{
A student participation assessment scheme for effective teaching and learning
}

\author{
Bader Ahmed Abuid \\ Directorate General of Technological Education, Oman
}

\begin{abstract}
In this paper a systematic and well-defined student participation assessment scheme for college courses is proposed. The scheme supports the involvement of students in a variety of areas of participation within and outside the classroom with the aim of improving their learning. The scheme addresses mostly the challenges related to the practicality of the structure and design of the assessment. It also addresses the subjectivity of grading student participations. Areas of participation are widened to allow the faculty more accurate information about the conduct of each individual student towards more objective assessment. In addition, it provides the faculty with the flexibility to select areas that best fit the learning outcomes, nature of the course, availability of time and resources, and class atmosphere. The proposed scheme is initiated and developed using feedback from the teaching staff of Nizwa College of Technology, (NCT) through a survey and open discussion. The results indicate that over two thirds of the surveyed staff show agreement with the concept of assessing participation and find the scheme design clear and systematic, while $82 \%$ of them perceive the scheme as effective in improving the motivation and learning of students.
\end{abstract}

\section{Introduction}

Student involvement in the teaching and learning process has various advantages: it motivates students, makes their study interesting, maintains a dynamic class, allows students to learn from each other, promotes learning, and builds confidence and trust among students. Student involvement happens by different means; conventional ones include assignments, project work, case studies, presentations, etc. Other means, which are the focus of this paper, are less conventional, incorporating different kinds of student participation inside the classroom, as well as outside the classroom via internet portals and smartphones. This paper explores the benefits of a participation assessment instrument, faculty perspectives, challenges associated with student participation, and factors that increase its effectiveness. The grading of participation plays an important role to ensure an effective learning-teaching process, and the result of grading of participation has to be considered as part of the course grade, usually part of the continuous assessment grade. The paper also focuses on different areas of student participation inside and outside the classroom, with the aim of systemizing assessment and developing an assessment scheme that is more objective, more flexible and easier to perform. Such scheme should increase the motivation and promote the learning of students in the GCC region, particularly male students, who may have less interest in study, face difficulty in communication in English language, and be less attentive in class.

\section{Literature review}

Over the past five decades, various investigations have been undertaken and documented to develop in-class student participation and its grading (Rocca, 2010). During this development period, there has been some apparent resistance to formalizing grading of student participation. For example, at Seattle University, although $93 \%$ of courses include class participation as a component of course grades, informal discussions with professors showed that they prefer to do it by impressionistic means (Bean \& Peterson, 1998). These faculty used class participation primarily 
as a 'fudge factor' in computing a final course grade at the end of the semester; as a result, Bean \& Peterson's informants generally recommended against the grading of class participation.

During the last decade, as will be seen from the literature review below, noticeable progress has been made to demonstrate advantages of and investigate challenges to more acceptable and effective student participation and its grading. However, challenges related to practicality and objectivity persist (Mello, 2010).

Various studies (e.g. Knight \& Wood, 2005; Cohen, 2008) indicate that participation of students is the key to an engaged class and better learning. It allows the students to practice speaking and persuasive skills, and increases their ability to listen. However, what matters is the concept of voluntary participation (Vandrick, 2000; Rocca, 2010). Some students who may be better prepared or just more vocal participate more than others, while those who do not participate are considered lazy and are usually penalized (Vandrick, 2000). Also, the assessment of student participation is often done based on general criteria for which contributors are classified into outstanding, good, adequate, non-participant and unsatisfactory (Tyler, 2008). However, classification depends on faculty's observation and interpretation of the student's performance (Mello, 2010). This leaves the door open for subjectivity in the assessment of participation and suggests a need for a more reliable grading scheme that allows continuous monitoring of the learning of each individual student.

In order to grade participation, it is first necessary to understand the participation process and how to stimulate students to contribute and get involved in the teaching and learning activity. The process, as explained in the Teacher Handbook of the National University of Singapore, (NUS, 2009), is very creative and its effectiveness depends on many aspects. Some of the aspects are the frequency of participation, quality of participation, attitude to work, interest in the subject, oral skills and interpersonal skills. The NUS Handbook explains that good quality participation could vary and may include: seeking and or giving information, offering opinions, arguing, clarifying, synthesizing, identifying problems, formulating solutions, applying information, etc. It also clarifies that the kind of the questions asked by a student and the quality of the answers given, which reflects the degree of understanding and the ability to articulate ideas clearly and coherently, show the broad area of effective and good quality participation.

Active student participation is driven by many factors, including the faculty role, the grading of participation and the student attitude. Instructors play a pivotal role in creating a positive climate for participation (Salter \& Persaud, 2003). Tips for faculty were published by Washington and Waterloo universities (University of Waterloo, 2012) with a focus to improve and increase class participation. The instructions underline the importance of the faculty role through interaction, devoting time, fostering an ethos of participation, planning, devising activities and shaping the environment of the class session so as to encourage participation and allow all participants the opportunity to learn.

To play an effective role, the assessor has to be aware of the complexities that accompany participation. Nickerson (2005) discusses some suggestions for instructors to let students feel safe to participate; for example students should not feel humiliated or ridiculed in class. She focuses on simple techniques for increasing class participation and gives suggestions for controlling students who are over-participators. Petress (2006) encourages active student involvement in class. He points out that class participation must be operationally defined, validly measured and clearly understood by both faculty and student. He also explains what is meant by effective class participation and includes teacher's behaviors to be avoided. 
The second important factor to improve and increase the process is the grading of participation. Bean \& Peterson (1998) believe that grading class participation sends a positive message to students:

grading class participation can send positive signals to students about the kind of learning and thinking an instructor values. (p.1)

It gives signals about the kind of learning and thinking the student should aim for, such as growth in critical thinking, active learning, development of listening and speaking skills needed for career success, and the ability to join a disciplined conversation. Bean \& Peterson found that when students see that their participation is being graded regularly and consistently, they adjust their study habits accordingly and come prepared for active participation. They thus suggest having a scoring rubric of assessment analogous to holistic or analytic rubrics; however no comprehensive and systematic procedure is explained, only separate guidelines for some practices, like the assessment of "student discussion" and "cold calling" are suggested to guide the faculty to decide the scoring for each student.

McDonald (2006) tried to quantify procedures to assess participation because many viewed this aspect of assessment as a 'giveaway' on a subjective base. Brady \& Stegemann (2010) implemented grading using a slip system to increase student participation. Their findings supported much of the literature on class participation and they concluded that

grading students does increase participation and [participation] clearly only works to motivate them when graded. (Brady \& Stegemann, 2010, p. 239).

They also indicated that progressive release of marks throughout the semester encourages greater participation. Grading of class participation has been found to encourage even "low-responding students" to participate (Foster et al., 2009).

Faculty perspectives on grading student participation are comprehensively discussed by Mello (2010). In his study, he mentioned that faculty fall into three categories: those who "firmly believe in the merits of graded class participation and not only practice it, but swear by such practice", those who "absolutely abhor and not only see no value to it but argue passionately against it", and those who are "reluctantly engage in it due to departmental or college standards or mandates" (Mello, 2010, p.1). He explores and discusses in depth the main criticisms and benefits of grading student participation. The main criticisms raised by faculty who are against it are: grading is highly subjective with difficulty in interpreting student performance; it can be burdensome and timeconsuming; it can be threatening to students with a more passive interaction style, particularly international students; and it can be of little added value when students are focused on the quantity rather than the quality of participation.

On the other hand, the benefits of grading class participation, as seen by implementers and demonstrated by other researchers cited by Mello (2010) are: it generally results in better prepared students; it encourages students to exchange experiences; it facilitates actual-world learning and presentation of material; it makes students ready for involvement on the job; it emphasizes outcomes of attitude, which are difficult to measure using traditional methods of assessing classroom behavior; it teaches students to think and react quickly 'on their feet'; it can't be 'faked', as students need to attend class and visibly demonstrate their understanding; and it enhances the depth of learning through different viewpoints and experiences of students from diverse backgrounds.

Through exploring the criticisms and benefits of assessment of participation, Mello (2010) focuses on addressing four issues for effective participation assessment: clearly defining participation, managing participation, addressing subjectivity, and rethinking the role of the instructor in a participation-oriented class. Also, to impact the efficacy of grading class participation, the author 
highlights the consideration of: absolute grading (assessment of each individual student), on-call participation, frequency of feedback to students, class size, classroom environment, and the student culture. However, Mello does not, for example, provide empirical data about the proportions of the three categories of faculty; only alternative strategies, design issues and consideration of caveats for grading participation are suggested.

More benefits of grading class participation for faculty teaching and student learning are summarized in the Assessment Toolkit of the University of New South Wales Australia, (UNSW, 2012). The Toolkit highlights challenges for staff and students, like fairness to shy participants, class size and that the grading of class participation might be hindered by the absence of faculty experience and skills in smoothing active classroom learning. However, only strategies of good assessment practice, and general guidelines for the participation assessment with example rubrics are given.

The third factor driving active participation is student attitude. Sariefe \& Klose (2008) surveyed 155 students (76\% response rate) to measure students' attitude towards in-class participation and its assessment. They found that $80.2 \%$ of students agreed that participation supports their learning; $61.3 \%$ of respondents accepted that participation grading encouraged them to prepare material prior to class; $91 \%$ agreed that in-class participation allows students understand material better; while $84.5 \%$ of students felt that with participation they acquired more in-depth information about the subject. Furthermore, they concluded that international learners (Asian from China, Hong Kong, Taiwan, India, Vietnam and Tongan) not only benefit from assessing in-class participation, but actually feel interested and enjoy this type of assessment.

Similarly, Brady \& Stegemann (2010) extended their study of student participation using a slip system (see above) to investigate student concerns about participation and its grading, using a questionnaire with 28 questions distributed to 55 male and female students. They concluded that: the majority of students were accustomed to, liked and felt comfortable with class discussions; students were satisfied (mean 3.09/5) with their participation but perceived increased advance preparation for class (mean 3.42/5); they also had the feeling that they acquired and understood more when participating (mean 3.53/5); they appeared not too concerned with dissatisfaction, embarrassment or criticism in class; in general, they accepted the concept but perceived the slip mechanism as unnecessary.

Other researchers (Eff, 2004; Dancer \& Kamvounias, 2005) suggest involving students in assessment to reduce subjectivity and assess class participation fairly and reliably. Student peer assessment is proposed to support faculty in gaining more complete information on student performance. They consider that student peer evaluation can provide additional information in certain circumstances for the assessment of groups of students responsible for presentations or class projects, allowing the instructor to assign a more accurate class participation grade. However there is a possibility of gender bias as identified by the authors.

From the literature, and as indicated by research studies including those discussed above, it is clear that student participation assessment is a potentially important tool to improve participation and promote student learning. It is also evident that there is a need for a clearer and more systematic scheme for grading participation, which allows continuous monitoring and collection of more information about the learning of each individual student. There is a need for a scheme that considers all sorts of participation inside and outside the classroom (see next section), and gives flexibility to the faculty to adjust meeting the course and student requirements. The main arguments against the grading of student participation (Mello, 2010) might be addressed, except the one concerning faculty comfort. This is the most critical issue as some perceive the process as cumbersome and time-consuming. However, keeping in mind the advantages of involving students 
in an interactive teaching and learning process, the current study proposes an assessment scheme with a clearly defined and systematic procedure to tackle the practicality and enhance the objectivity of grading. Such a scheme might be very beneficial to increase the motivation and promote the learning of students in the Gulf region, particularly male students, as some have less interest in study, face difficulty in communication in English language or are less attentive in class. The proposed scheme was initiated by the author and further developed using feedback and discussion by staff at Nizwa College of Technology (NCT).

In the following sections, the methodology followed to achieve the aim of this study is explained, as well as details of possible areas of participation inside and outside the class room; how to do the assessment in a clearly systematic and flexible manner; weight of areas of participation; and the design of the assessment sheet. Results of a faculty survey and open staff discussion are analyzed, presented and discussed, and finally conclusions are drawn.

\section{Methodology}

The study involved two stages. The first is designing the scheme of assessment of student participation while the second is evaluating its implementation. For the first stage, consideration has been made to address the challenges related to the subjectivity, structure and practicality of grading student participation. Accordingly, the design focuses first on expanding the dimensions of participation, i.e. to include more areas inside and outside the classroom. The main areas considered were: answering questions addressed to the class, answering question addressed to the individual, long in-class written answers, volunteered participation, group discussion, e-learning participation, attendance and disruptive responses. Widening the areas of participation gives faculty an opportunity to collect more information about student learning, thus increasing the reliability and objectivity of the assessment. It also gives more freedom and flexibility for the teaching faculty to select areas most suitable to course outcomes and student needs. Second, the design focuses on the establishment of a clear practical procedure for assessing participation with a flexible assessment sheet design; thus it provides a record to follow up the participation performance of each individual student. During the design stage, the draft scheme was announced to the faculty in the college Moodle portal for negotiation and discussion (Appendix B). This helped to create awareness, collect feedback and improve the design further.

In the second stage, the developed scheme was proposed to the college faculty for optional implementation. Then a staff feedback survey (see Table 4) was carried out after two semesters of implementation in order to measure faculty perspectives on student participation and its grading, the clarity and practicality of the design of the scheme, and the objectivity and effectiveness of the scheme for student motivation and learning. Also, during implementation the portal discussion continued to share ideas and collect more feedback.

\section{Areas of student participation and their assessment}

Various contexts are available for student participation. In the author's opinion, participation should not be limited to class time only: it should consider all activities of the course within and outside the classroom, particularly with the implementation of modern learning tools (e-learning/ m-learning using computers, smartphones, iPads, etc.). This will offer students more opportunity to react in ways they feel comfortable with, and also allow staff members to select the areas that most suit the nature of their courses, desired learning outcomes and student needs.

The following sections describe eight areas of participation available in the proposed assessment scheme, with some details on the weight for each area and how it can be assessed. Theoretically, the average weight for each is around $13 \%$ of the total assessment grade (total of 100 divided by 8 
areas). In the discussion below, a somewhat different weight is suggested for each area based on its merits; however, this is subject to adjustment based on the nature of the course and the relative importance of each area as seen by the assessor.

\section{Answering general oral questions}

Asking oral questions for the whole class is the method most often used to check students' understanding (Angelo \& Cross, 1993; Abuid, 2007), however not all students participate in this way: usually the same few students dominate in answering. Rewarding students who answer will encourage others to think and take part. The drawback of this method is that some students feel shy to participate, some fear giving wrong answers, and some show no interest in responding. To avoid such drawbacks, some NCT staff advised giving half points for students giving wrong answers, in order to encourage hesitant and shy students (see Table 4, Q13 and the open discussion in Appendix B). Nickerson (2005) perceives wrong answers as a positive contribution because they can be instructive for other students. According to this concept of encouragement, and based on a scale of ten points for each answer, grading may start from a minimum of five unless the student gives no answer; although it is true that some students may abuse the system, faculty can easily detect such behavior from its frequency. This area is suggested to have a weight of ten percent of the total grade of participation.

\section{Answering when called upon}

This area involves the teacher asking a question of a particular student selected randomly, i.e. 'answers upon call' or the 'cold-calling' mode (Bean \& Peterson, 1998). The general questioning described in the previous section does not ensure that all students participate; however, 'cold calling' can be used to encourage each individual student to take part and be involved. To make all students responsible for taking part in this area, it is suggested here that answering this type of questioning should be compulsory in the class. The students should be aware of it, and the faculty should ensure equal opportunity to each student. Questions could include: meaning of terminology, solving a problem (on paper or the board), doing calculations, giving an interpretation, reasoning, linking, synthesizing, giving procedures, explaining a point, drawing a diagram/ sketch, stating definitions/ laws/ formulae, rephrasing/ summarizing, giving real life examples, giving ideas for solutions, etc.

The same encouragement strategy mentioned above may be implemented here, i.e. to give five points out of ten even for wrong answers. This area of assessment is suggested by the author to carry more weight, for example $15 \%$, as its aim is to involve and engage all students to take part and be ready for the class.

\section{Long in-class written answers}

This is involves asking all students at the beginning of the class to answer a written question/s, with an open time-frame possibly lasting the whole class period.

The faculty can distribute papers at the beginning of the class with a few questions related to the main or important topics of the lecture. Time is kept open for students to answer during the whole class time. Answer scripts can then be collected at the end of the class. If necessary, different sets of questions could be used with different groups of students, to avoid malpractice. This method could keep the students attentive throughout, thinking of answers; some challenging questions with indirect answers may be included. In this case, it is advisable to create awareness among students to prepare for the class in advance, to make the task achievable. The method may lead students to look up answers from the handout/ textbook in the class, so it is suggested that it be done without a time limit and with open resources to give more encouragement to students. 
The disadvantage of the written questions may be the pressure they cause to the faculty, as feedback needs to be given to students. However, it can be conducted two to three times in the term/semester. This area of assessment is suggested to carry $20 \%$ as its aim is to involve and engage all students in taking part and being attentive in class.

\section{Volunteered participations}

This area of participation encourages students' initiative to articulate useful information, substantiate their own views, ask important questions, argue logically, respond intelligently to others' views, give new ideas, etc. It is expected that relatively few students have the ability and talent to participate in this way; however, they need to be appraised positively among their peers, which could encourage others to try. This area can be used to distinguish outstanding students, and it is suggested to carry a weight of ten percent of the participation grade.

\section{Group discussion}

Group discussion in the class is another form of participation which can be motivated through assessment. It is usually used to encourage teamwork, sharing ideas, exchanging experience, taking different roles, building leadership, reaching consensus, taking decisions, and reaching solutions.

The drawback of this area is the difficulty in assessing each individual member of the group reliably; typically, all members of the group are given the same grade, irrespective of the activity and creativity of each individual. Another drawback is that discussion held in one group is not accessible to other groups; also, sometimes the class period is not long enough or the nature of the course does not support holding such activity. Because of these drawbacks, this area is suggested to be given a weight of ten percent, with more exact information about the student gathered from other areas of participation.

\section{E- Learning participation}

E-Learning is a powerful tool for participation, which can be used by students within and outside the classroom. Online media such as internet portals, smartphones, etc. provide an effective, easy and open communication and interaction facility with many advantages. These media are public and accessible to all from any place, and all students can see what others do and have done; they are open, without any time limitation, with no necessity for face to face meetings or simultaneous presence of parties. This resolves, for example, the problem of unavailability of staff or student during office hours.

The assessment of participation of each individual student is not a tedious process for the faculty, as it is in open time and continuous. The assessment may include the number of participations, taking a leading role, quality of questions raised, quality of answers given, speed of answering, initiations, course related activities, etc. Some e-learning portals may provide an automatic assessment by the portal itself, as suggested by Wu \& Chen (2005).

Because of the significance of this area, it is preferable to be introduced to all courses to enhance involvement of students and promote continuous learning. This area is suggested to carry more weight, e.g. 30\%; however, this percentage can be altered if the faculty finds this necessary.

\section{Attendance}

Students' attendance is a controversial issue in higher education institutions; however, in my opinion, regular attendance of students in class is an important factor in the learning process, otherwise there would be no need for faculty and classes. Increasing student attendance in class depends on several factors, one of which is its assessment as a participation activity by the student, i.e. to motivate students who regularly attend and to encourage others not to miss classes without 
good reason. It is preferable to assess the attendance by the end of the term/ semester. Some higher education institutions leave the attendance policy within the hands of the faculty, while others set a general policy with a limit for the maximum percentage of absenteeism. In any case, and to reach a compromise for this debatable area, it is suggested to give it less weight, such as ten percent, with grading depending on the regulations followed by the faculty or the institution. For example, if the maximum allowed percentage of absence is $30 \%$, as implemented in NCT (after which a student may be barred from taking the final exam), then students with more than $90 \%$ attendance may be considered to have full points, those with more than $80 \%$ attendance, $70 \%$ of the points, and those with more than the lowest acceptable percentage of attendance $(70 \%$ attendance), half the points. Likewise the assessment for different limits of absenteeism may be adjusted accordingly.

\section{Disruptive participation}

It could happen that a student might (intentionally or not) disrupt the class or misuse the opportunity for student participation. For such cases negative grading is suggested in order to discourage any disruptive or discourteous actions like vague, repetitive, irrelevant or disrespectful responses. This suggestion is in line with policies followed by some universities to deal with negative student behavior (e.g. Nilson, 2010).

It is preferable that the implementation of this negative assessment be used for the purpose of correcting behavior; hence, it is recommended that it be cancelled later if student participation improves. The suggested weight of this area is $-20 \%$. Student behavior in the class, if there is any disorder, is expected to improve by this process.

With the implementation of this area, the students' learning discipline and study commitment might be improved. According to the experience of the author with male students in the GCC region, it sometimes happens that a student joins the class with little interest in studying. In such cases, the student does not pay attention to class and even starts to make negative contributions (talking, making fun, playing with cellphone, etc.) which disrupt the class. The faculty can easily detect such a student and with a smile can send the student a message through the suggested negative assessment. However, the same principle applies to cancelling the negative assessment, if the faculty notices improvement in the behavior of the particular student.

\section{Student participation assessment process}

Teaching staff should use their judgment to select a balance of participation areas that suit the learning outcomes, course nature, availability of time and resources, class atmosphere, and students' background and needs.

Student participation assessment can be started from the first class; however, to raise awareness among students and to have an idea of their level, it is necessary first to introduce and discuss the issue with students, and to explain the importance of participation and its assessment. Following this, a formative assessment without grading (Angelo \& Cross, 1993; Abuid, 2007) gives a measure of their level(s). The faculty can then decide on the proper area(s) of student involvement and when to start graded assessment.

The grading weight of participation should be considered as part of the total course grade. In NCT, this weight is considered as part of the $30 \%$ continuous assessment, while $20 \%$ and $50 \%$ are given for the mid-term and final exams respectively. The grading weight of the student-participation assessment depends on the assessment policy of the institution. However, if not specified, it may be suggested to carry five to $15 \%$ of the total course work grade; Brown University (Tyler, 2008) uses a rate of $15 \%$. 
When the areas of participation are decided, the grading weight for each area and the number of times to be assessed can be identified as per the decision of the faculty. To facilitate this, the following guidelines may help to answer several questions that may cross the mind of the assessor.

\section{Participation assessment guidelines}

The following general guidelines were used for the implementation of the proposed scheme of assessment of student participation:

- Students should preferably be given an induction to prepare them for effective participation within and outside the class. They should be made aware that sometimes a question may be asked of a particular student at any time without specifying names in advance.

- The faculty should decide on the areas of participation that best suit the course outcomes, resources and student background. The proper assessment weight for each area also needs to be decided.

- Equal participation opportunities should be ensured for all students, i.e. equal number of times of assessment for each student.

- The total number of times of assessment during the whole semester per student for all selected areas can be decided by the faculty based on the number of students, the class hours per week and the duration of the semester; this may range from ten to 20 times per student during the semester.

- The number of times of assessment per student for each area can be calculated by multiplying the total number of times of assessment by the percentage weight of the particular area (e.g. if the total number of assessment per student in a semester is 20 , then the number of times a student should be assessed in an area of $20 \%$ weight is $20 \times 20 \%$, i.e. four times).

- Grading of a student's answer is preferably done in points, e.g. ten points. This widened scale will help the faculty to ensure more accurate assessment of students. The total points for each area could then be calculated by multiplying the number of times for each area by the points per one time (ten).

- The total grading of the student participation assessment may be assumed to carry ten percent of the course work assessment unless specified by the assessment policy of the institution.

- A student participation assessment sheet similar to the attendance sheet should be designed and used as a record (see completed examples in Appendix A1, Appendix A2).

- The final grade of participation for each student is calculated by scaling down the total number of points gathered by the student using the following formula:

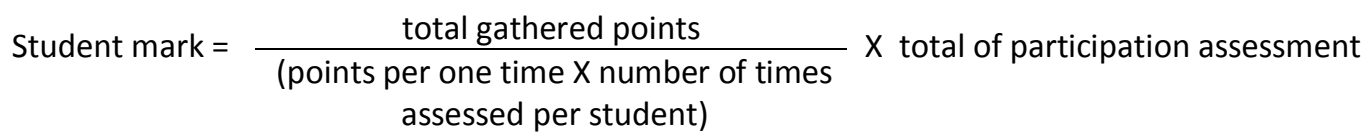

e.g. for student No. 1 in Appendix A1, who collected 117 total points, the mark is $117 /$ ( 10 points per one time $\times 20$ assessments per semester) $\times 10$ which equals 5.9.

- It is recommended to announce the participation records periodically to students during the term to give them an opportunity to monitor and adjust their performance.

\section{Student participation assessment sheet design}

With an aim to make the scheme more practical for implementation, an assessment sheet was designed, which provides faculty with guidance and a continuous record to follow up each individual student. This sheet was designed by making use of the guidelines mentioned above. The guidelines give the faculty the choice and flexibility to modify the design so as to suit the nature of the course, faculty and students as mentioned above. 
The sheet design depends on the assessment parameters, which should be identified first. For example Lecturer $X$ might select all the eight areas of assessment mentioned above with their suggested weight, as shown in Table 1, and might use the highest (20) times of assessment for each student in a three-month semester. This results in a total of 400 (for a 20 student class) assessments for all students during the whole semester which implies that, for a course with 3 hour per week, it is necessary to ensure an assessment of 10 to 12 students every week [400/(3month $x$ 4 weeks per month $x$ 3hrs lectures per week)]. The number seems large; however in each class hour it is required to ensure an assessment for only three to four students (10-12 students per week/3hrs lectures per week).

Other assessment parameters like the number of times of assessment and the total points for different areas (shown in the third and the second columns before the last of Table 1) were calculated based on the weight of each area as explained in the guidelines above.

Table 1: Student participation assessment parameters by Lecturer $\mathrm{X}$.

\begin{tabular}{|c|c|c|c|c|c|c|}
\hline \# & $\begin{array}{c}\text { Area of } \\
\text { Assessment }\end{array}$ & Details & $\begin{array}{c}\% \\
\text { Weight }\end{array}$ & $\begin{array}{l}\text { No. of } \\
\text { times } \\
\text { assessed }\end{array}$ & $\begin{array}{l}\text { No. of } \\
\text { points }\end{array}$ & $\begin{array}{c}\text { Grade } \\
\text { out of } \\
10 \%\end{array}$ \\
\hline 1. & $\begin{array}{l}\text { Answers to } \\
\text { general questions }\end{array}$ & $\begin{array}{l}\text { Questions to be posed orally to all } \\
\text { students without specifying a particular } \\
\text { student. }\end{array}$ & $10 \%$ & 2 & 20 & 1 \\
\hline 2. & Answers upon call & $\begin{array}{l}\text { Oral question to a particular student. } \\
\text { Each student should be asked the same } \\
\text { number of times during the whole } \\
\text { semester. }\end{array}$ & $10 \%$ & 2 & 20 & 1 \\
\hline 3. & $\begin{array}{l}\text { Long in-class } \\
\text { written answers } \\
\text { (whole class) }\end{array}$ & $\begin{array}{l}\text { A question paper for all students during } \\
\text { the whole class period. }\end{array}$ & $20 \%$ & 4 & 40 & 2 \\
\hline 4. & $\begin{array}{l}\text { Volunteered } \\
\text { participation }\end{array}$ & $\begin{array}{l}\text { Volunteering information, substantiation } \\
\text { of own views, logical argumentation, } \\
\text { responding intelligently to other views } \\
\text { and giving new ideas. }\end{array}$ & $10 \%$ & 2 & 20 & 1 \\
\hline 5. & Group discussion & $\begin{array}{l}\text { Group discussions assessed with same } \\
\text { points given to each member of each } \\
\text { group. }\end{array}$ & $10 \%$ & 2 & 20 & 1 \\
\hline 6. & e-Learning forum & $\begin{array}{l}\text { Number and quality of participations, } \\
\text { number of times accessed, leading } \\
\text { group/forum discussion, raising } \\
\text { questions, answering, helping others, etc. }\end{array}$ & $30 \%$ & 6 & 60 & 3 \\
\hline 7. & Attendance & $\begin{array}{l}90 \% \text { or more attendance: full points; } \\
\text { more than } 80 \% \text { attendance: } 70 \% \text { of } \\
\text { points; } \\
\text { more than } 70 \% \text { attendance, } 50 \% \text { of } \\
\text { points. }\end{array}$ & $10 \%$ & 2 & 20 & 1 \\
\hline \multicolumn{3}{|c|}{ TOTAL } & $100 \%$ & 20 & 200 & 10 \\
\hline 8. & $\begin{array}{l}\text { Disruptive } \\
\text { responses* }\end{array}$ & $\begin{array}{l}\text { Negative points to discourage any } \\
\text { disruptive/discourteous: vague, } \\
\text { repetitive, unrelated, disrespectful } \\
\text { responses }\end{array}$ & $-20 \%$ & 4 & -40 & -2 \\
\hline
\end{tabular}

* Cancelled when student's performance improves, as described above. 
Starting from the design parameters given in Table 1, the assessment sheet for Lecturer $\mathrm{X}$ was designed as shown in Appendix A1. The sheet provides history records about each student and tells which student has the priority to be assessed so as to ensure equal number of assessment for all students. The first row of the assessment sheet shows the week number necessary to guide and help the faculty to know which activity needs to be done and when. The third row of the assessment sheet includes the number of points which are to be given to each area according to the number of times of assessment as specified by Table 1 . The last two columns represent the total points collected by each student and the scaled-down results out of ten (according to the guidelines above), respectively.

The assessment sheet was prepared as an Excel spreadsheet for automatic calculation of final student participation results. This also allows records of participation to be announced and displayed periodically to students (at any time decided by the faculty) to give them opportunity to monitor and adjust their performance.

In order to reflect the flexibility of the scheme, Table 2 shows a second sheet, designed for Lecturer $\mathrm{Y}$, with fewer areas (five) and with fewer assessments of ten times per student in the whole semester. The resulting assessment sheet is shown in Appendix A2.

Table 2: Student participation assessment parameters by Lecturer $\mathrm{Y}$.

\begin{tabular}{|c|l|l|c|c|c|c|}
\hline$\#$ & \multicolumn{1}{|c|}{$\begin{array}{c}\text { Area of } \\
\text { Assessment }\end{array}$} & \multicolumn{1}{|c|}{ Details } & $\begin{array}{c}\% \\
\text { Weight }\end{array}$ & $\begin{array}{c}\text { No. of } \\
\text { times } \\
\text { assessed }\end{array}$ & $\begin{array}{c}\text { No. of } \\
\text { points }\end{array}$ & $\begin{array}{c}\text { Grade } \\
\text { out of } \\
10 \%\end{array}$ \\
\hline 1. & $\begin{array}{l}\text { Answers to } \\
\text { general } \\
\text { questions }\end{array}$ & $\begin{array}{l}\text { Questions to be posed orally to all } \\
\text { students without specifying a particular } \\
\text { student. }\end{array}$ & $20 \%$ & 2 & 20 & 2 \\
\hline 2. & $\begin{array}{l}\text { Answers upon } \\
\text { call }\end{array}$ & $\begin{array}{l}\text { Oral question to a particular student. Each } \\
\text { student should be asked the same number } \\
\text { of times during the whole semester. }\end{array}$ & $30 \%$ & 3 & 30 & 3 \\
\hline 3. & e-Learning forum & $\begin{array}{l}\text { Number and quality of participations, } \\
\text { number of times accessed, leading } \\
\text { group/forum discussion, raising questions, } \\
\text { answering, helping others, etc. }\end{array}$ & $40 \%$ & 4 & 40 & 4 \\
\hline 4. & Attendance & $\begin{array}{l}\text { 90\% or more attendance: full points; } \\
\text { more than 80\% attendance: 70\% of points; } \\
\text { more than 70\% attendance, 50\% of points. }\end{array}$ & $10 \%$ & 1 & 10 & 1 \\
\hline
\end{tabular}

* Cancelled when student's performance improves, as described above.

The second design reduces the total number of total assessments to 200 for all students in the whole semester and leads to the assessment of an average of two to three students each class hour. In this way, the scheme can be less cumbersome and time consuming.

After developing the scheme with the above described sample designs of the assessment sheet, it was proposed to the college faculty for optional implementation. A survey on staff feedback was then carried out after two semesters of implementation. For this purpose, a questionnaire with a variety of questions (most relevant ones are shown in Table 4) was prepared and distributed to staff to measure: their beliefs and perspectives on student participation and its grading (questions 1 
to 7); the clarity, structure, and practicality of the design of the scheme (questions 8 to 13); the objectivity and effectiveness of the scheme on student motivation and learning (questions 14 to 18). Moreover, before and during implementation, an open online discussion using Moodle was held with staff to clarify queries, create awareness, share ideas, exchange experiences, collect more feedback and adjust some scheme parameters (Appendix B).

The structure of the assessment scheme and the challenges for design and subjectivity are issues of concern to faculty rather than to students; thus, the survey was limited to faculty rather than including students. Students' perspectives and attitude regarding participation in general and its grading in particular are well investigated and documented by researchers as discussed above (e.g. Sariefe \& Klose, 2008; Brady \& Stegemann, 2010). In spite of this, the current scheme could be further developed in the future to cover particular aspects and preferences from the students' side as well.

\section{Results and discussion}

A sample of 25 faculty from the IT department of NCT with the description shown in Table 3 was surveyed. All surveyed faculty except one had implemented the proposed scheme on the assessment of student participation. They were given the flexibility to decide the areas of assessment and its weight, and design their own assessment sheets based on the given examples. The results of the survey are shown in Table 4 below.

Table 3: Survey sample.

\begin{tabular}{ll}
\hline Number of lecturers surveyed & 25 \\
\hline Female respondents & 5 \\
Male respondents & 20 \\
Response Rate & $100 \%$ \\
\hline
\end{tabular}

Table 4: Results of the survey on the student participation assessment scheme.

\begin{tabular}{|c|c|c|c|c|c|}
\hline \multirow[t]{2}{*}{$\#$} & \multirow[b]{2}{*}{ Question } & \multicolumn{3}{|c|}{ Frequency } & \multirow{2}{*}{$\begin{array}{c}\text { \% Agree/ } \\
\text { Strongly } \\
\text { Agree }\end{array}$} \\
\hline & & $\begin{array}{l}\text { Agree/ Strongly } \\
\text { agree }\end{array}$ & $\begin{array}{l}\text { Not } \\
\text { agree }\end{array}$ & Invalid & \\
\hline Q1. & $\begin{array}{l}\text { I believe in the involvement of } \\
\text { students in the teaching \& learning } \\
\text { process. }\end{array}$ & 24 & 1 & 0 & $96 \%$ \\
\hline Q2. & $\begin{array}{l}\text { I believe in the concept of grading } \\
\text { student participation. }\end{array}$ & 17 & 7 & 1 & $68 \%$ \\
\hline Q3. & The process is not a waste of time. & 22 & 2 & 1 & $88 \%$ \\
\hline Q4. & $\begin{array}{l}\text { The participation is necessary for my } \\
\text { course. }\end{array}$ & 23 & 1 & 1 & $92 \%$ \\
\hline Q5. & $\begin{array}{l}\text { The time of my class is enough to } \\
\text { accommodate the process. }\end{array}$ & 15 & 6 & 4 & $60 \%$ \\
\hline Q6. & $\begin{array}{l}\text { The process is not cumbersome and } \\
\text { does not impose pressure on me. }\end{array}$ & 10 & 13 & 2 & $40 \%$ \\
\hline Q7. & I used to implement the activity & 11 & 13 & 1 & $44 \%$ \\
\hline
\end{tabular}




\begin{tabular}{|c|c|c|c|c|c|}
\hline \multirow[b]{2}{*}{ Q8. } & \multicolumn{5}{|l|}{ before as part of my teaching. } \\
\hline & $\begin{array}{l}\text { The scheme is clear to design for } \\
\text { implementation }\end{array}$ & 19 & 3 & 3 & $76 \%$ \\
\hline Q9. & $\begin{array}{l}\text { The procedure of participation is } \\
\text { more systematic. }\end{array}$ & 19 & 1 & 5 & $76 \%$ \\
\hline Q10. & $\begin{array}{l}\text { The scheme helped me to modify } \\
\text { the assessment sheet to suit my } \\
\text { course and students. }\end{array}$ & 15 & 8 & 2 & $60 \%$ \\
\hline Q11. & $\begin{array}{l}\text { The weight given to each area of } \\
\text { assessment is reasonable. }\end{array}$ & 20 & 4 & 1 & $80 \%$ \\
\hline Q12. & $\begin{array}{l}\text { I accept giving points to } \\
\text { participations as per the assessment } \\
\text { scheme. }\end{array}$ & 18 & 6 & 1 & $72 \%$ \\
\hline Q13. & $\begin{array}{l}\text { I accept giving half the points to } \\
\text { students giving wrong answers. }\end{array}$ & 13 & 9 & 3 & $52 \%$ \\
\hline Q14. & $\begin{array}{l}\text { Students kept attentive in the class } \\
\text { with participation assessment. }\end{array}$ & 21 & 4 & 0 & $84 \%$ \\
\hline Q15. & $\begin{array}{l}\text { Grading of participation motivated } \\
\text { my students. }\end{array}$ & 24 & 1 & 0 & $96 \%$ \\
\hline Q16. & $\begin{array}{l}\text { It has improved the learning of my } \\
\text { students. }\end{array}$ & 23 & 1 & 1 & $92 \%$ \\
\hline Q17. & $\begin{array}{l}\text { The scheme gives more information } \\
\text { about student learning and allowed } \\
\text { me to identify weak students. }\end{array}$ & 20 & 5 & 0 & $80 \%$ \\
\hline Q18. & $\begin{array}{l}\text { I noticed some new and creative } \\
\text { participation from students. }\end{array}$ & 14 & 9 & 2 & $56 \%$ \\
\hline
\end{tabular}

Figure 1 shows the results from the first part of the survey, about the perspectives and belief of faculty in student participation and its grading (questions 1 to 7 in Table 4). It is interesting to notice that the majority of the respondents (96\%) accept and believe in the concept of participation and the involvement of students in the teaching and learning process (Q1 in Table 4); however, only $68 \%$ believe in grading of this participation (Q2). On the other hand, $88 \%$ of respondents believe that the process is not a waste of time (Q3), although $60 \%$ consider the activity as cumbersome and/or imposing some pressure on faculty ("Not agree" in Q6). Similarly, 92\% (Q4) feel that participation is necessary for their courses with $60 \%$ (Q5) of them are able to manage the activity within the class time, however only $44 \%$ (Q7) were used, in one way or another, to implement the grading of participation even before the proposed scheme.

Although $96 \%$ of the surveyed staff implemented the proposed scheme, the first part of the questionnaire, particularly Q2 and Q7 clarify how many staff are for, against or uncertain regarding the assessment of student participation. $68 \%$ of staff accept the grading of participation (Q2) and $44 \%$ were used to doing this in their own way previously (Q7); this means that $24 \%(68 \%-44 \%)$ of staff could be considered "reluctant" graders in Mello's terms (2010, p1 - see p. 3 above). 
It appears that those who believe firmly in grading participation are the largest group among these faculty (44\%), while $32 \%$ are against it and $24 \%$ reluctant. Also, the average result ( $70 \%$, see Fig. 1 ) of faculty perspectives and beliefs in student participation and its grading is, in general high and encouraging.

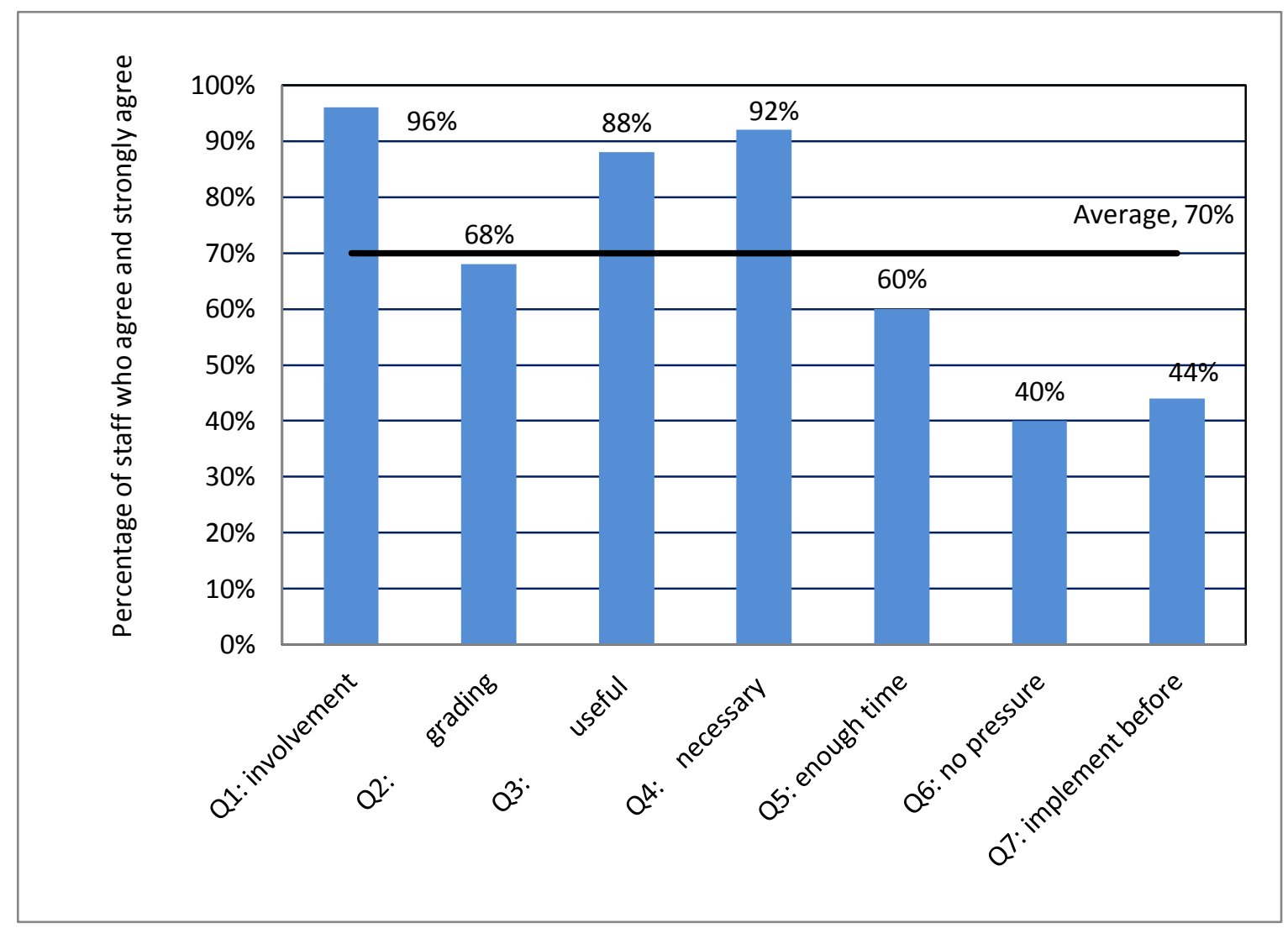

Figure 1: Survey results related to staff perspectives and beliefs in grading student participation

The feedback of faculty on the clarity of the scheme, its structure and design (Table 4, questions 8 to 13) shows an average agreement of $69 \%$ among the surveyed staff (Figure 2). In particular, it shows that $76 \%$ of staff agree or strongly agree with the clarity of the assessment scheme and its systematization, respectively (Q8 and Q9). Also, 60\% of them agree or strongly agree with the necessity of the scheme's flexibility that allows modification to fit the outcomes, time, resources and students (Q10). In addition, it can be noticed that $80 \%$ of the faculty accept the suggested weight given to different areas of participation (Q11), while $72 \%$ accept the strategy of giving points rather than marks (Q12). However, only 52\% agree with giving half points to students giving wrong answers (Q13).

The third part of the survey (questions 14 to 18 ) indicates that an average of $82 \%$ of the surveyed faculty agree or strongly agree with the scheme's effectiveness in motivating students and improving their learning (Figure 3). $96 \%$ of the staff observed that the scheme encourages and motivates students (Q15) and 84\% of them found that it keeps students attentive in the class (Q14), while $56 \%$ of them noticed some new, creative participations from students (Q18). Student learning is also observed to improve, as $92 \%$ of the surveyed staff agreed or strongly agreed with this statement (Q16). In addition, $80 \%$ of the staff perceived that the scheme gives more information on student learning and helped in detecting weak students (Q17). Detection of this group of students makes it easy to provide them special attention and arrange for remedial tutorials. 


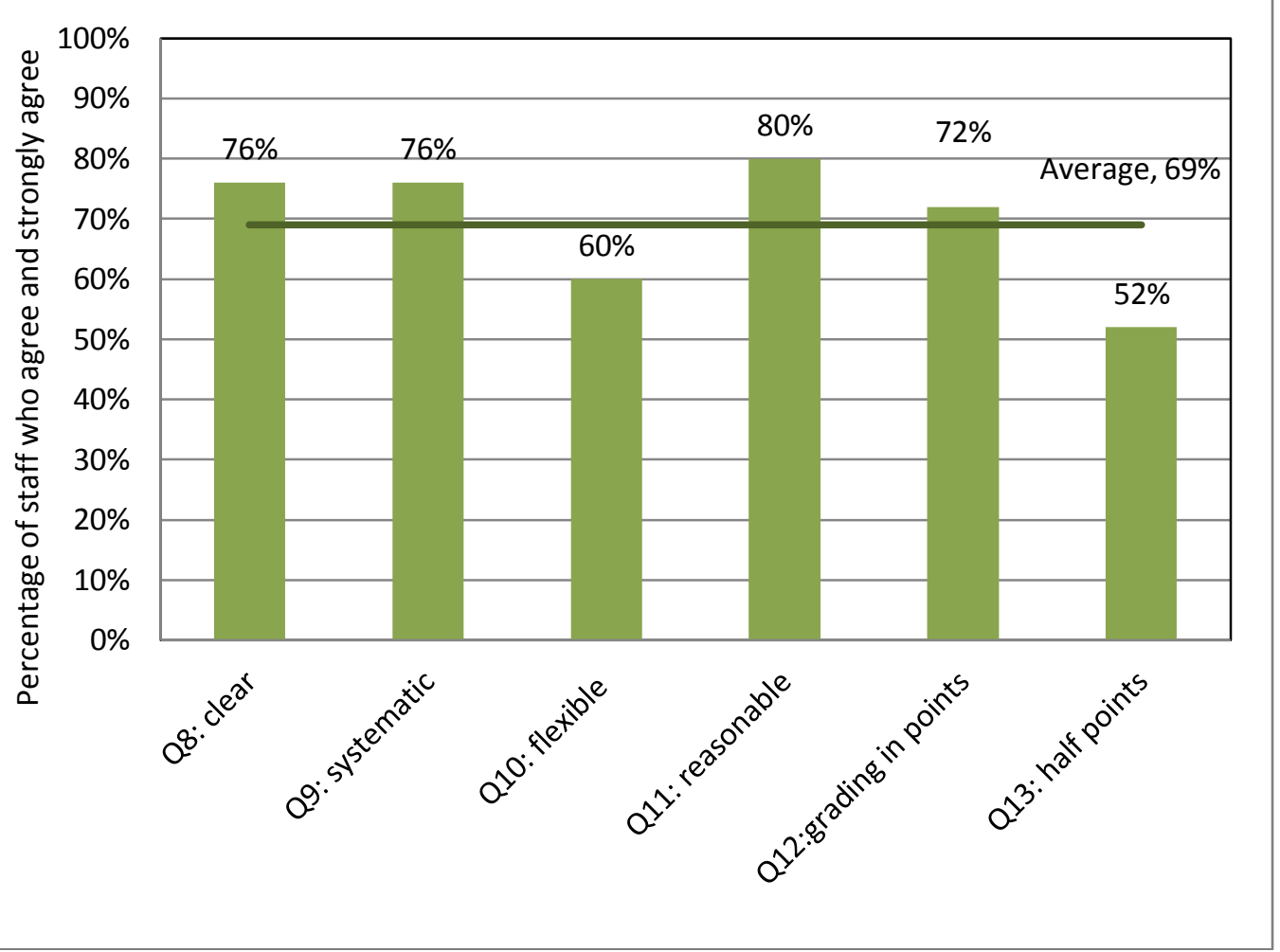

Figure 2: Staff feedback on structure, clarity and design of the assessment scheme

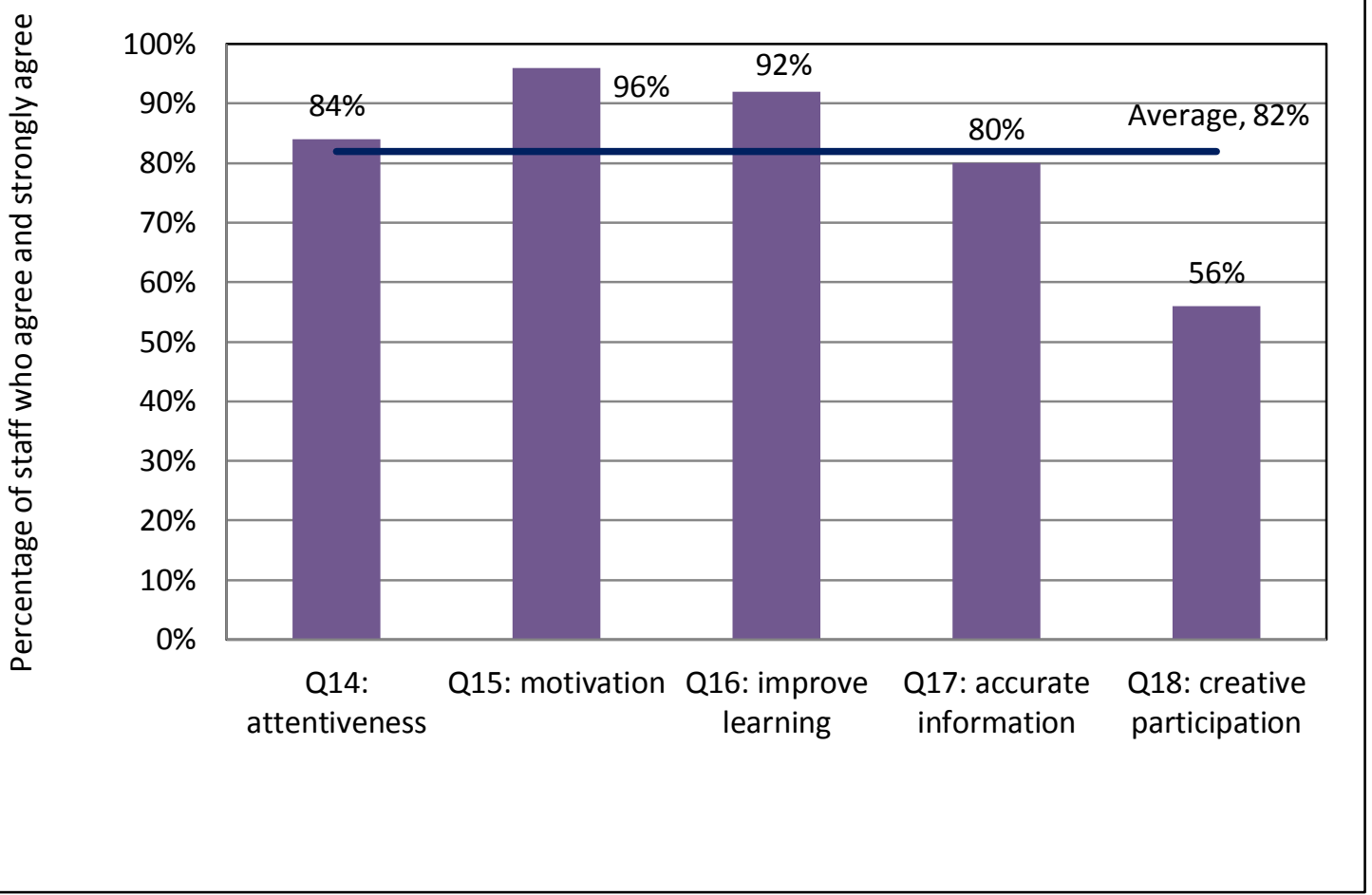

Figure 3: Staff feedback on the effectiveness of the assessment scheme

The open discussion held before and during implementation (Appendix B) resulted in some interesting comments that helped in clarifying the scheme and creating more awareness among 
faculty. It also supported in adjusting some parameters of the scheme. For example, some staff anticipated that low weight of the whole process, e.g. five percent of the course grade, does not give significance to participation and students may ignore it; instead they suggest having it at 10-15\%. However, with increased weight, others consider that it may be abused by lenient faculty. Another useful comment was that some staff feel that rewarding wrong answers may be abused by students. Based on this a question was asked in the survey (Q13), which revealed that $52 \%$ expressed acceptance of this strategy. Consequently it is agreed to offer students half points to encourage them to take part with full discretion to the faculty in limiting abusing students. The discussion led also to widening the areas of participation to outside class, particularly through elearning portals.

It is true that the grading of student participation may be a tedious, cumbersome and time consuming process particularly for large classes; however many faculty believe in and enjoy changing students from passive to active learners and converting the teaching and learning process towards a more interactive kind. The results after implementation of the suggested scheme indicated that over $40 \%$ of the faculty embrace the concept of grading participation and usually implement it and $24 \%$ are reluctant but see some benefit in it, while almost one third $(32 \%)$ are against the idea. It also showed that over two-thirds of the surveyed faculty expressed agreement with this scheme in particular, and found it clear and systematic, while over $80 \%$ of them perceived improvement in student learning.

\section{Conclusions}

A scheme for the assessment of student participation with a flexible application has been proposed. The scheme covers a wide range of possible areas that allow students to participate within and outside the class. It also provides the faculty with flexibility to design an assessment sheet that incorporates the areas of participation that most suit the learning outcomes, the nature of the course, availability of resources, and the students' characteristics and background. The scheme provides a systematic base for the motivation of students. It encourages them to be involved in the teaching and learning process for the sake of promoting their learning and improving their performance. The systematization of the scheme supports the activation of students with equal opportunity through a variety of methods. This increases the opportunity for better learning and allows the faculty to collect enough and more accurate information about each individual towards more objective assessment of participation.

Feedback collected after implementation of the scheme indicated that over two thirds of the surveyed staff agree or strongly agree with the concept and find the scheme design clear and systematic, while $82 \%$ of them consider the scheme effective in improving the motivation and learning of students.

\section{Acknowledgments}

Praise be to the Almighty Allah for everything He gave us. The author would like to express his deep thanks and gratitude to the ex-Dean of the College Dr. Al Ghassani for his assistance and encouragement. Acknowledgments go to all those who supported the scheme and contributed sincerely and honestly in the open discussion and to those who conducted the survey for their invaluable assistance and patience. The author wishes also to express his deep gratitude to Ms. Lynette Brummer for allocating part of her precious time to check the language. Lastly, the author wishes to express love and gratitude to his beloved family, for their understanding and patience. 


\section{References}

Abuid, B. A (2007). Assessment of teaching \& learning. First Symposium on Improving Teaching \& Learning in College of Technology, ITL-CT, 9-10 ${ }^{\text {th }}$ April 2007. NCT, Oman.

Angelo, T. \& Cross, K. P. (1993). Classroom assessment techniques: a handbook for college teachers, $2^{\text {nd }}$ edition. Jossey Bass Higher and Adult Education Series.

Bean, J. C. \& Peterson, D. (1998). Grading classroom participation. New directions for teaching and learning, 74, 33-40.

http://www.fresnostate.edu/academics/documents/participation/grading_class_participation.pdf

Brady, C.S. \& Stegemann, N. (2010). Assessing methods to improve class participation. 2010 EABR \& ETLC Conference Proceedings. Dublin, Ireland.

Cohen, M. (2008). Participation as assessment: political science and classroom assessment techniques. Journal of PS-Political Science and Politics, Vol. 41, Issue 3, pp. 609-612.

Dancer, D. \& Kamvounias, P. (2005). Student involvement in assessment: a project designed to assess class participation fairly and reliably. Assessment \& Evaluation in Higher Education, Vol. 30, No. 4, August 2005, pp 445-454.

Eff, E. A. (2004). An endogenous measure of class participation. Journal of Economics and Finance Education, Volume 3, Number1, 2004, p38.

Foster, L. N., Krohn, K. R., McCleary, D. F., Aspiranti, K.B., Nalls, M. L., Quillivan, C. C., Taylor, C. M. \& Williams, R. L. (2009). Increasing low-responding students' participation in class discussion. Journal of Behavioral Education, Volume 18, No. 2, pp. 173-188.

Knight, J. K. \& Wood, W. B. (2005). Teaching more by lecturing less. Journal of CBE - Life Sciences Education (Cell Biology Education), Volume 4, Issue Winter, pp. 298-310.

McDonald, K. (2006). Increasing the class participation experience for engineers. Proceedings of the ASEE Annual Conference and Exposition. Chicago, IL.

Mello, J. A. (2010). The good, the bad and the controversial: the practicalities and pitfalls of the grading of class participation, Academy Educational Leadership Journal, Source Vol. 14. Source Issue 1. http://www.freepatentsonline.com/article/Academy-Educational-LeadershipJournal/229228145.html.

Nickerson, S. (2005). Class participation: suggestions for instructors. New York University, Center for Innovation in Teaching \& Learning.

http://w4.stern.nyu.edu/citl/articles/ClassParticipation.pdf

Nilson L. B. (2010). Maintaining student discipline. Clemson University, USA. (Portions of this chapter were adapted from Chapter 7, "Preventing and responding to classroom incivility," in Nilson, L. B. (2010). Teaching at its best: A research-based resource for college instructors. San Francisco: Jossey-Bass.). http://sites.iiitd.ac.in/indous/papers/Paper_Linda\%20Nilson_(2).doc

National University of Singapore [NUS] (2009). Assessing participation in class. Learning to teach, teaching to learn: A handbook for NUS teachers. National University of Singapore. http://www.cdtl.nus.edu.sg/handbook/assess/class.htm

Petress, K. (2006). An operational definition of class participation. College Student Journal, Dec. 2006, Vol. 40 Issue 4, p821, Dec. 2012.

Rocca, K. A. (2010). Student participation in the college classroom: an extended multidisciplinary literature review. Communication Education, Vol. 59, No. 2, April 2010, pp. 185_213 
Salter, D. W. and Persaud, A. (2003). Women's views of the factors that encourage and discourage classroom participation. Journal of College Student Development, Vol. 44, Issue 6, pp. 831844.

Sariefe, S \& Klose, M. (2008). Students' attitude toward assessing in-class participation. Paper presented at the Teaching \& Learning Conference, Eastern Institute of Technology, Hawkes Bay, 1-3 October 2008

Tyler, J. (2008). Class participation assessment guidelines. Harriet W. Sheridan Center for Teaching and Learning. Brown University. http://www.docstoc.com/docs/10258293/ClassParticipation-(PDF).

University of Waterloo (2012). Promoting effective classroom participation. http://uwaterloo.ca/centre-for-teaching-excellence/teaching-resources/teachingtips/assessing-student-work/grading-and-feedback/promoting-effective-participation

University of New South Wales [UNSW] (2012). Grading class participation. Assessment Toolkit of the University of New South Wales, Australia. http://teaching.unsw.edu.au/assessingclassroom-participation.

Vandrick, S. (2000). Language, culture, class, gender and class participation. Paper presented at TESOL Annual International Convention, Vancouver, Canada, March 2000.

Wu, Y. F. B. \& Chen, X. (2005). e-Learning assessment through textual analysis of class participation. Proceeding of the $5^{\text {th }}$ IEEE International Conference on Advanced Learning Technologies, ICALT 2005, Vol. 2005, Article No. 1508707, pp. 388-390. 


\section{Appendix A1}

Appendix A1. Class- Participation Assessment Sheet - by Lecturer X

Course code:

Level:

Course Lecturer:

Department/Center:
Course Title:

Semester:

Academic Year:

\begin{tabular}{|c|c|c|c|c|c|c|c|c|c|c|c|c|c|c|c|c|c|c|c|c|c|c|c|c|c|c|c|c|}
\hline \multicolumn{3}{|c|}{ week number } & \multirow{2}{*}{\multicolumn{2}{|c|}{\begin{tabular}{|c|} 
open \\
$\begin{array}{c}\text { General } \\
\text { questions } \\
, 10 \%\end{array}$ \\
\end{tabular}}} & \multirow{2}{*}{\multicolumn{2}{|c|}{\begin{tabular}{|c|} 
open \\
Answers \\
upon \\
call, $10 \%$
\end{tabular}}} & \multirow{2}{*}{$\begin{array}{l}\text { w2 } \\
\text { qu } \\
\end{array}$} & \multirow{2}{*}{\multicolumn{3}{|c|}{\begin{tabular}{l|l|l|} 
w5 & w8 & w10 \\
open time \\
writen \\
estions, $20 \%$
\end{tabular}}} & \multirow{2}{*}{\multicolumn{2}{|c|}{$\begin{array}{c}\text { open } \\
\text { Creative } \\
10 \%\end{array}$}} & \multirow{2}{*}{\multicolumn{2}{|c|}{\begin{tabular}{|c|c|}
$\mathrm{w} 4$ & $\mathrm{w7}$ \\
$\begin{array}{c}\text { Group } \\
\text { Discussion } \\
10 \%\end{array}$ \\
\end{tabular}}} & \multirow{2}{*}{ w3 } & \multicolumn{2}{|c|}{ w5 w7 } & w9 u & \multirow{2}{*}{\multicolumn{2}{|c|}{$\begin{array}{l}\text { w11 } \\
\text { w12 } \\
30 \%\end{array}$}} & \multirow{2}{*}{\multicolumn{2}{|c|}{$\begin{array}{c}\text { end of } \\
\text { semester } \\
\begin{array}{c}\text { Attendance, } \\
10 \%\end{array}\end{array}$}} & \multirow{2}{*}{\multicolumn{4}{|c|}{$\begin{array}{c}\text { open } \\
\begin{array}{l}\text { Disruptive } \\
\text { sponses, }(-20) \%\end{array}\end{array}$}} & \multicolumn{2}{|c|}{ Auto } \\
\hline \multirow[t]{2}{*}{ \# } & \multirow[t]{2}{*}{ ID } & \multirow[t]{2}{*}{ Name } & & & & & & & & & & & & & & \multicolumn{3}{|c|}{ e-learning, 30\% } & & & & & & & & & Total & Mark \\
\hline & & & 10 & 10 & 10 & 10 & 10 & 10 & 10 & 10 & 10 & 10 & 10 & 10 & 10 & 10 & 10 & 10 & 10 & 10 & 10 & 10 & -10 & -10 & -10 & -10 & 200 & 10 \\
\hline 1 & MA0001 & $\operatorname{xxxx} \operatorname{xxxxx} \operatorname{xxxxxx}$ & & & 5 & 5 & 5 & 6 & 6 & 7 & & & 5 & 6 & 7 & 8 & 9 & 8 & 10 & 10 & 10 & 10 & & & & & 117 & 5.9 \\
\hline 2 & MA0002 & Xxxx Xxxxx $x x x x x x$ & 10 & 10 & 10 & 10 & 10 & 10 & 10 & 10 & 10 & 10 & 10 & 10 & 10 & 10 & 10 & 10 & 10 & 10 & 10 & 10 & & & & & 200 & 10.0 \\
\hline 3 & MA0003 & Xxxx xxxxx xxxxxx & & & 5 & 5 & 0 & 6 & 5 & 5 & & & 5 & & & & & & 0 & 10 & 5 & 5 & -10 & & & & 41 & 2.1 \\
\hline 4 & MA0004 & xxxx xxxxx xxxxxx & 9 & 8 & 7 & 5 & 7 & 8 & 10 & 9 & & 9 & 6 & 6 & 7 & 8 & 9 & 9 & 10 & 10 & 10 & 10 & & & & & 157 & 7.9 \\
\hline 5 & MA0005 & $\operatorname{xxxx} \operatorname{xxxxx} \operatorname{xxxxxx}$ & 9 & 10 & 8 & 10 & 10 & 10 & 10 & 10 & 10 & & 10 & 10 & 10 & 10 & 10 & 10 & 10 & 10 & 10 & 10 & & & & & 187 & 9.4 \\
\hline 6 & MA0006 & $\operatorname{xxxx} \operatorname{xxxxx} \operatorname{xxxxxx}$ & & 7 & 5 & 5 & 5 & 6 & 6 & 7 & 8 & & 5 & 5 & 7 & 8 & 9 & 9 & 10 & 10 & 10 & 10 & & & & & 132 & 6.6 \\
\hline 7 & MA0007 & $\operatorname{xxxx} \operatorname{xxxxx} \mathrm{xxxxxx}$ & & & 5 & 9 & 9 & 8 & 10 & 10 & & & 8 & 10 & 8 & 8 & 9 & 8 & 10 & 10 & 10 & 10 & & & & & 142 & 7.1 \\
\hline 8 & MA0008 & $\operatorname{xxxx} \operatorname{xxxxx} \operatorname{xxxxxx}$ & & & 6 & 7 & 8 & 6 & 6 & 7 & & & 6 & 7 & 7 & 8 & 9 & 8 & 10 & 10 & 10 & 10 & & & & & 125 & 6.3 \\
\hline 9 & MA0009 & xxxx xxxxx xxxxxx & & & 5 & 5 & 7 & 6 & 6 & 7 & & & 6 & 6 & 0 & \begin{tabular}{|l|}
7 \\
\end{tabular} & 6 & 7 & 10 & 0 & 7 & 7 & -10 & & & & 82 & 4.1 \\
\hline 10 & MA0010 & $\operatorname{xxxx} \operatorname{xxxxx} \operatorname{xxxxxx}$ & & & 5 & 5 & 0 & 6 & 6 & 7 & & & 5 & 5 & 7 & 8 & 9 & 9 & 10 & 10 & 10 & 10 & & & & & 112 & 5.6 \\
\hline 11 & MA0011 & Xxxx xxxxx xxxxxx & & & 5 & 5 & 5 & 6 & 6 & 8 & & & 8 & 8 & 9 & 9 & 9 & 10 & 10 & 10 & 10 & 10 & & & & & 128 & 6.4 \\
\hline 12 & MA0012 & Xxxx XXXXx Xxxxxx & & 7 & 5 & 6 & 6 & 6 & 6 & 7 & & & 6 & 7 & 7 & 8 & 9 & 7 & 10 & 10 & 10 & 10 & & & & & 127 & 6.4 \\
\hline 13 & MA0013 & $\operatorname{xxxx} \operatorname{xxxxx} \mathrm{xxxxxx}$ & & & 5 & 5 & 5 & 6 & 6 & 9 & & & 8 & 9 & 9 & 10 & 9 & 10 & 10 & 10 & 10 & 10 & & & & & 131 & 6.6 \\
\hline 14 & MA0014 & Xxxx xxxxx xxxxxx & & & 5 & 7 & 0 & 6 & 7 & 7 & & & 6 & 6 & 7 & 8 & 9 & 8 & 0 & 10 & 10 & 10 & & & & & 106 & 5.3 \\
\hline 15 & MA0015 & $\mathrm{Xxxx}$ XXXXx Xxxxxx & 10 & 10 & 10 & 10 & 10 & 10 & 10 & 10 & 10 & 10 & 10 & 10 & 10 & 10 & 10 & 10 & 10 & 10 & 10 & 10 & & & & & 200 & 10.0 \\
\hline 16 & MA0016 & $\operatorname{xxxx} \operatorname{xxxxx} \operatorname{xxxxxx}$ & & & 5 & 5 & 5 & 6 & 6 & 7 & & & 5 & 6 & 5 & 8 & 9 & 9 & 10 & 10 & 10 & 10 & & & & & 116 & 5.8 \\
\hline 17 & MA0017 & Xxxx xxxxx xxxxxx & 7 & 6 & 8 & 5 & 5 & 6 & 6 & 7 & & 9 & 10 & 7 & 7 & 8 & 9 & 8 & 10 & 10 & 10 & 10 & & & & & 148 & 7.4 \\
\hline 18 & MA0018 & \begin{tabular}{|l}
$x x x x$ xxxxx xxxxxx \\
\end{tabular} & & & 5 & 6 & 5 & 6 & 6 & 7 & & & 8 & 6 & 6 & 8 & 9 & 9 & 10 & 10 & 10 & 10 & & & & & 121 & 6.1 \\
\hline 19 & MA0019 & $\operatorname{xxxx} \operatorname{xxxxx} \mathrm{xxxxxx}$ & & & 5 & 7 & 5 & 6 & 7 & 8 & & & 8 & 8 & 9 & 8 & 9 & 10 & 10 & 10 & 10 & 10 & & & & & 130 & 6.5 \\
\hline 20 & MA0020 & $\operatorname{xxxx} \operatorname{xxxxx} \operatorname{xxxxxx}$ & 9 & 8 & 10 & 8 & 7 & 9 & 6 & 10 & 8 & \begin{tabular}{l|l}
10 \\
\end{tabular} & 10 & 8 & 8 & 8 & 8 & 8 & 10 & 10 & 10 & 10 & & & & & 175 & 8.8 \\
\hline
\end{tabular}




\section{Appendix A2}

\begin{tabular}{|c|c|c|c|c|c|c|c|c|c|c|c|c|c|c|c|c|}
\hline & & & & & \multicolumn{8}{|c|}{ Appendix A2. Class- Participation Assessment Sheet- by Lecturer Y } & & & & \\
\hline \multicolumn{2}{|c|}{ Course code: } & & & & & & & & & Course & itle: & & & & & \\
\hline \multicolumn{2}{|c|}{ Level: } & & & & & & & & & \multicolumn{2}{|c|}{ Semester: } & & & & & \\
\hline \multicolumn{3}{|c|}{ Course Lecturer: } & & & & & & & & Acade & Year: & & & & & \\
\hline \multicolumn{17}{|c|}{ Department/Center: } \\
\hline \multicolumn{3}{|c|}{ week number } & \multicolumn{2}{|c|}{ open } & \multicolumn{3}{|c|}{ open } & w3 & w6 & w9 & w11 & $\begin{array}{c}\text { end of } \\
\text { semester }\end{array}$ & & & \multicolumn{2}{|c|}{ Auto } \\
\hline \multirow[t]{2}{*}{ \# } & \multirow[t]{2}{*}{ ID } & \multirow[t]{2}{*}{ Name } & \multicolumn{2}{|c|}{$\begin{array}{c}\text { Answer to } \\
\text { general } \\
\text { questions, } 20 \%\end{array}$} & \multicolumn{3}{|c|}{$\begin{array}{l}\text { Answers upon call, } \\
30 \%\end{array}$} & \multicolumn{4}{|c|}{ e-learning, $40 \%$} & $\begin{array}{c}\text { Attendance, } \\
10 \%\end{array}$ & \multicolumn{2}{|c|}{$\begin{array}{r}\text { Disruptive } \\
\text { Responses, } \\
(-20) \%\end{array}$} & \multirow{2}{*}{$\begin{array}{r}\text { Total } \\
100\end{array}$} & \multirow{2}{*}{$\begin{array}{r}\text { Mark } \\
\mathbf{1 0}\end{array}$} \\
\hline & & & 10 & 10 & 10 & 10 & 10 & 10 & 10 & 10 & 10 & 10 & -10 & -10 & & \\
\hline 1 & MA0001 & xxxx xxxxx xxxxxx & 6 & 7 & 5 & 7 & 5 & 6 & 6 & 7 & 7 & 10 & & & 66 & 6.6 \\
\hline 2 & MA0002 & xxxx xxxxx xxxxxx & 10 & 10 & 10 & 10 & 10 & 10 & 10 & 10 & 10 & 10 & & & 100 & 10.0 \\
\hline 3 & MA0003 & xxxx xxxxx xxxxxx & & & 5 & 8 & 0 & 6 & 5 & 5 & 6 & 5 & -10 & & 30 & 3.0 \\
\hline 4 & MA0004 & $\mathrm{xxxx}$ xxxxx xxxxxx & 9 & 8 & 7 & 7 & 7 & 8 & 10 & 9 & 8 & 10 & & & 83 & 8.3 \\
\hline 5 & MA0005 & xxxx xxxxx xxxxxx & 9 & 10 & 8 & 10 & 10 & 10 & 10 & 10 & 10 & 10 & & & 97 & 9.7 \\
\hline 6 & MA0006 & xxxx xxxxx xxxxxx & 6 & 7 & 5 & 6 & 5 & 6 & 6 & 7 & 8 & 10 & & & 66 & 6.6 \\
\hline 7 & MA0007 & xxxx xxxxx xxxxxx & 5 & 5 & 5 & 9 & 9 & 8 & 10 & 10 & 9 & 10 & & & 80 & 8.0 \\
\hline 8 & MA0008 & xxxx xxxxx xxxxxx & & & 6 & 7 & 8 & 6 & 6 & 7 & 6 & 10 & & & 56 & 5.6 \\
\hline 9 & MA0009 & xxxx xxxxx xxxxxx & 5 & 5 & 5 & 6 & 7 & 6 & 6 & 7 & 6 & 7 & -10 & & 50 & 5.0 \\
\hline 10 & \begin{tabular}{|l|} 
MA0010 \\
\end{tabular} & xxxx xxxxx xxxxxx & 6 & 6 & 5 & 5 & 0 & 6 & 6 & 7 & 7 & 10 & & & 58 & 5.8 \\
\hline 11 & MA0011 & xxxx xxxxx xxxxxx & & & 5 & 8 & 5 & 6 & 6 & 8 & 6 & 10 & & & 54 & 5.4 \\
\hline 12 & \begin{tabular}{|l|} 
MA0012 \\
\end{tabular} & xxxx xxxxx xxxxxx & 6 & 7 & 5 & 7 & 6 & 6 & 6 & 7 & 6 & 10 & & & 66 & 6.6 \\
\hline 13 & MA0013 & xxxx xxxxx xxxxxx & 5 & 5 & 5 & 6 & 5 & 6 & 6 & 9 & 7 & 10 & & & 64 & 6.4 \\
\hline 14 & MA0014 & xxxx xxxxx xxxxxx & 6 & 7 & 5 & 7 & 0 & 6 & 7 & 7 & 8 & 10 & & & 63 & 6.3 \\
\hline 15 & MA0015 & xxxx xxxxx xxxxxx & 10 & 10 & 10 & 10 & 10 & 10 & 10 & 10 & 10 & 10 & & & 100 & 10.0 \\
\hline 16 & \begin{tabular}{|l|} 
MA0016 \\
\end{tabular} & xxxx xxxxx xxxxxx & & & 5 & 7 & 5 & 6 & 6 & 7 & 5 & 10 & & & 51 & 5.1 \\
\hline 17 & MA0017 & xxxx xxxxx xxxxxx & 7 & 6 & 8 & 7 & 5 & 6 & 6 & 7 & 7 & 10 & & & 69 & 6.9 \\
\hline 18 & \begin{tabular}{|l|} 
MA0018 \\
\end{tabular} & Xxxx xxxxx xxxxxx & & & 5 & 6 & 5 & 6 & 6 & 7 & 5 & 10 & & & 50 & 5.0 \\
\hline 19 & MA0019 & xxxx xxxxx xxxxxx & 6 & 5 & 5 & 8 & 5 & 6 & 7 & 8 & 7 & 10 & & & 67 & 6.7 \\
\hline 20 & MA0020 & xxxx xxxxx xxxxxx & 9 & 8 & 10 & 8 & 7 & 9 & 6 & 10 & 8 & 10 & & & 85 & 8.5 \\
\hline
\end{tabular}

Course Lecturer

Head of Department/Center 


\section{Appendix B}

\section{Sample feedback on the suggested student-participation assessment scheme}

by Axxx - Thursday, 5 February 2009, 01:35 PM

Dear colleagues,

I know that the idea behind this assessment is not clear for some of you, so it is my pleasure to discuss this issue here.

Please feel free to comment and raise any question and let us share ideas for having better teaching and learning. It is for the sake of our students.

Just an example, I'll mention here one question raised by one staff saying that: we are assessing students using different methods; assignments, quizzes, exams, etc. so why we need to do this, we do not have time....

The answer is very simple because the idea behind the suggested assessment (which I am sure that it is being implemented in a certain way by some of the staff) is to have a more dynamic class with more interaction between the staff and students. Also to motivate students to do better and enhance their learning.

It will not take much time; it will reduce the effort and lecturing time by allowing students to take part. It will just replace the classical questions which the faculty is usually used to raise to his/her students: is it clear? did you understand?, do you have any question?,,, and all the class is keeping silent....

For example if you ask a particular student about the meaning of a certain terminology you explained before and give him/her a mark based on his/her response, you will encourage $\mathrm{him} /$ her to listen carefully to you and make him/her thinks of bringing the tool to get the meaning. Such question may take (1) min time, thus if you assess 10 students in each class you will not lose more than 10 min but the benefit will be very high.

Waiting your words with regards

$\operatorname{Axxx}$

by Nxxx - Wednesday, 18 February 2009, 10:07 PM

Nxxx, dated 18-02-2009

Dear Axxx,

Assalam Alaikkum,

1. The idea of awarding marks to class participation is very good. We may set aside $5 \%$ marks for this in the beginning. If we see many students actively come forward for participation we shall even increase it to $10 \%$.

2. How to award the marks: here my suggestion is that 1 mark for each activity of the student like 
questions, answers etc. will be difficult to award. ie. if he answers a question partially, how much we can give him? To solve this situation I have another idea. Each time we may award points to the students for their participation in the class activities out of 10. Then at the end of the semester we may calculate the marks based on 500 points $=5$ marks or so. If each activity marks is based on max 10, we can very conveniently determine the level of the student. Easy to give between 0 to 10 each time, giving more flexibility to the teacher. This will convince the student also in the long run.

In general I welcome the idea. But in this case the lecturer should be ready to set apart some time to do such assessment.

thanks and regards

Nxxx

by Axxx - Saturday, 21 February 2009, 01:02 PM

Thanks Mr. Nxxx

It is a good suggestion but 500 points is too much, if for example you give each participation 10 points then you need to do the questioning 50 times for each student which is impractical. Better to have 150 to 200 points with 15 to 20 opportunity of class -participation for every student during the whole semester

regards

by SDS - Saturday, 21 February 2009, 12:43 PM

Sir,

I completely agree in rewarding marks for the class participation. But I don't think that class participation means" only asking questions and collecting the good or best answers".

Our class will not move smoothly without the participation of all our students. There will be slow learners also. When we ask questions and expect answers from the students, we must not forget about these slow learners. They won't be able to answer quickly to our questions. That doesn't mean that he/she is weak in our subject. So we can ask a question to the whole class (not to a particular student) and whatever idea the student has let him/ her write in his notebook. Take a round to check the answers. In this way we can even find out

i) whether all the students are following our lecture or not

ii) the difficulty for each and every student to attempt that particular question

iii) the level of each and every student

and we can help them individually. When our teaching proceeds in this way, after a week or two, we will be completely familiar with the level of each and every student and also we can see the improvement in their performance inside the class. Also we can find out the slow learners, the week students, average and above average students and can offer the help which each one of them wanted inside the class room itself. I feel in this way we can make all most all of them to participate actively in the class. We can start assessing their performance in each semester, after two teaching weeks. Every day's performance ( including the use of calculators )can be assessed 
by giving points ( as Mr. Nxxx suggested)

by Axxx - Saturday, 21 February 2009, 03:58 PM

I agree fully with you, we have no doubt about the principle but the point you are raising is related to the method of implementation so as to cover all levels of students.... it is very good point,,, why not,,, but isn't it similar to the area of answers to written questions?

Regards

by SDS - Wednesday, 25 February 2009, 08:30 AM

Before we start giving marks for the class participation, I want the slow learners also to be brought to the competing level.

First identify the levels of each and every student, give them extra work, slowly bring them to participate actively in the class, and then start assessing all of them

Area No. 3 , some what sounds like a quiz, and it may not require active student participation to ensure the smooth running of the class.

Regards,

by Axxx - Saturday, 28 February 2009, 05:09 PM

Yes, what you are recommending is same as the formative assessment which will give feedback on the student background and on your teaching. This is in details explained in ch. 3 (articles 3.8, $3.9 \& 3.10$ ) of the academic staff manual distributed to all staff.

Regarding area 3 you mentioned: No, it is not a quiz because it is with open time, during the whole class from the beginning till the end keeping the student attentive to the lecturer to find the answer/s for the question/s given to him/her.

by KS - Saturday, 21 February 2009, 06:23 PM

Dear sir,

Thank you for creating a discussion forum on class participation. This will help us to implement policies with clarity.

I strongly agree that the class participation method of assessment will help in making the class more dynamic and interactive.

Can I satisfy class participation assessment area 3 with class participation assessment area 5 ?

Can we implement $10 \%$ of class participation marks for the students using Moodle? 
thank you.

by Axxx - Sunday, 22 February 2009, 03:47 PM

in my opinion, if we agree about the principle then the method of implementation could be open, you select the ones which suit the course and students

Regards

by SK - Sunday, 22 February 2009, 11:14 AM

Sir,

I agree with the proposal completely except for the weightage of marks given to class participation. In my opinion, $5 \%$ to $10 \%$ seems to be very low. I would like to suggest that the marks for class participation can be in the range of $10 \%$ to $15 \%$ of the course work. This method of assessment will, not only help in making the class more dynamic but also in meeting the aims of students' role in teaching and learning process.

Thank you

by

S.K.G, IT

by Axxx - Sunday, 22 February 2009, 03:53 PM

It is an arguable issue. Let us see the opinion of others.

My view is that we need to start with $10 \%$ percentage till all staff get involved,

Regards

by AL - Sunday, 22 February 2009, 09:31 PM

I think that $5 \%$ is enough for class participation since we are just starting to include this in the student's assessment. Staff should first agree on the standard procedure, techniques and policies of assessing class participation before thinking of changing this to a higher percentage.

by AL - Sunday, 22 February 2009, 02:16 PM

First of all I would like to thank Axxx for initiating a discussion forum regarding Class Participation. In the case where problem arises in the class or there are doubts about a particular topic 
discussed, any student could raise the issue "in the class" or in "forums" made available for them in Moodle. In this way, there will be equal class participation.

by Axxx - Sunday, 22 February 2009, 04:02 PM

Thanks for compliments

I agree with you but unfortunately not all students are able to access Moodle because of shortage of resources and some of them do not have the experience particularly in foundation. I agree to add one more point for giving marks to participations using Moodle.

Regards

by AJM - Sunday, 1 March 2009, 12:41 PM

Dear Axxx

Thanks a lot for the simple way in which you have explained how class participation can be evaluated. Most of the students in the class are very shy, by making them speak we are not only testing their knowledge but also helping in personality development. Moreover I have observed that students many a times can write a specific word but when it comes to pronouncing the word they cannot e.g Characteristics or some other simple words very often used in marketing. As a teacher I get an opportunity to correct the students. I am $100 \%$ with the idea of class participation.

by St - English Language Center, Tuesday, 7 April 2009, 09:00 AM

I think there are fundamental differences in the way we view what class participation is. For me, class participation is by definition:

- $\quad 100 \%$ voluntary

- largely student initiated

In your system $30 \%$ of what you call class participation, the student has to participate. And $50 \%$ of a student's class participation grade comes from answering the teacher's questions. Students are expected to answer questions correctly for participation points. This for me is not participation. This is a test of knowledge, a mini quiz, in which a student responds to a teacher and gets points for correct answers. So what's the difference between "the written questions method" and a quiz? I think class participation should involve more. It should encourage the student to become more active in every way in his or her learning. This means taking initiative, asking his or her own questions. And this sometimes includes asking stupid questions or questioning basic assumptions. Students need to feel free to take risks in class. If they are afraid that every comment will be graded, that willingness to go out on a limb may be quashed. Students will prefer safe answers or questions to new or counter-intuitive ones.

I would also be very hesitant to consider anything that happened outside of class when evaluating class participation. I think class participation is what happens inside the class, not outside. I think it's very important to encourage e-learning groups, and involvement outside of 
class. However, I also know that some students will go to great lengths to get good marks. Some might get their friends or family to contribute to a forum in their name. So in fact, there is no real way of knowing whether the student has really contributed or not.

Also, I think class participation should foster an atmosphere of cooperation, not competitiveness. We learn from each other. And good discussions or contributions help everybody. The motivation that arises out of teamwork is much more satisfying and probably more fruitful than fear-driven or competition-driven efforts. So how students engage in group and pair work should also be considered.

Finally, equal assessment opportunities cannot be assured if students are being asked different questions on different days. Some questions are bound to be easier than others.

I'm going to send a few articles that I found on the internet. Stephanie Nickerson includes a quote worth reading on the last page that talks about "right" and "wrong" answers. Two other articles include grading class participation grading scales (one is for younger learners, but it could easily be modified). I think they reflect what is generally considered to be class participation.

by Axxx - Wednesday, 8 April 2009, 09:52 AM

Thank you first for your valuable feedback and thank you second for the phrase "we learn from each other". Really, we need to foster this concept among our students which I think lies within the area of student participation_inside or outside the class. And now allow me to give feedback on the issues you raised.

- Yes, there is a fundamental difference in our understanding to participation. If the participation as you believe is kept $100 \%$ voluntary and student- initiated activity then every class the same students will take part repeatedly and usually few in number. This is not my finding; it is a fact that teachers face in most of their classes. I think the staff should play a major role in the process of participation in order to organize it and motivate other students to take part also. I believe that, part of that role is the assessment of the participation because there is no doubt when a student is being rewarded for something, this encourages him/her to do better and better, so assessment means reward and motivation. Positive assessment is motivation for excellence, while negative assessment means motivation to improve next time.

- Students through their participation are expected to give the correct answer, who said that? In the proposed scheme, the scale of assessment is made in terms of points (10 points for each participation). This gives the teacher flexibility to decide what the student deserves out of 10. I strongly agree and support the staff who said to give half the points (half the mark) for even wrong answers so as to encourage students to participate. Moreover, the students will learn why that answer is wrong, so they could avoid falling in such mistake, so I am totally against disappointing and embarrassing any student for wrong participation unless it is disruptive.

- The written questions method is different than the quiz because it is open and made for the whole class period. To be distributed at the beginning of the class and collected at the end before the students leave. By this way students will try to be attentive to the teacher during the whole class time so as to get the answers of the given questions or they come already prepared to class to ensure the answers, which in both cases enhances their learning.

- Taking initiatives, asking his/her own questions, etc is included in the area of "creative volunteering participation". Also full discretion is given to the staff to change the weight of 
each participation area so as to meet the nature of the course and the level of students. English, IT, Bus and Engineering courses are different from each other.

- Students need to feel free to take risk in class. If they are afraid that every comment will be graded, that willingness to go out on a limp may be quashed. Yes I agree that they should feel free to take risk in/outside the class but I do not agree that the assessment could make them afraid to participate. There is another factor which makes them afraid, it is the teacher. From experience, I found that fear is there within any student even when no grading of participation is considered. Some students feel afraid of giving wrong answers, they prefer to keep silent in class because of the bad feedback of some teachers. Most of the time, they feel afraid and shy of their bad communication language even if they know the right answer. So, all of this depends on the attitude of the teacher, he/she must not make them feel embarrassed or disappointed. I think that the suggestion of grading wrong answers positively with half the points may solve this problem.

- I think class participation is what happens inside the class, not outside. Yes I agree, but this is not the issue of discussion. The main issue is the participation itself, no mind it is inside or outside the class. I decided to change the phrase "class participation" to "student participation" so as to include both.

- Some students might get their friends or family to contribute to a forum in their name. This usually happens in all kinds of assignments, the copy past rule, photocopy, asking help of other teachers, friends, family, etc. It is a matter of integrity of both the student and the teacher. The teacher can discover this easily comparing the performance of each individual student in different disciplines and if there is some doubts, he/she has to take measure according to the plagiarism policy and rules of the college to discourage such behavior.

- I think class participation should foster an atmosphere of cooperation, not competitiveness. Why not both. Group discussion will foster cooperation, however other individual student participation may result in competition because it is human nature, but it should be free of selfishness which limits the cooperation. One example, one hard working student has more vocabulary than others and able to answer related questions better, then no one has control to limit other students from seeking the reason and compete each other.

- Teamwork/group discussion: Yes I agree that it is very fruitful and can be considered as one separate area of participation or together with the e-learning participation area (as discussed in sec 3.4 of the paper). The weight then can be increased. However all students in the group should be given the same grade, since the teacher will not be able to follow the performance of each individual except may be the leader.

- Some questions are bound to be easier than others: This is something healthy. It is under the full control of the teacher. The teacher policy should cover easy, moderate and challenging questions and should be a good player in the "Art of Questioning". 